\title{
Molecular and ultrastructural characterization of Haplosporidium diporeiae n. sp., a parasite of Diporeia sp. (Amphipoda, Gammaridea) in the Laurentian Great Lakes (USA)
}

\author{
Andrew D Winters ${ }^{1}$ and Mohamed Faisal ${ }^{2^{*}}$
}

\begin{abstract}
Background: The phylum Haplosporidia contains coelozoic and histozoic, spore-forming, obligate protozoan endoparasites that infect a number of freshwater and marine invertebrates including bivalves, crustaceans, and polychaetes. In amphipods, haplosporidians cause systemic infection resulting in a range of pathologies. While amphipods belonging to the genus Diporeia (Gammarideae) have been shown to host haplosporidians, the taxonomic relationship of the Diporeia haplosporidian(s) is largely unknown due to the lack of phylogenetic and detailed ultrastructural studies.
\end{abstract}

Methods: The infection characteristics and taxonomic identity of a haplosporidian infecting Diporeia spp. (Diporeia) were based on microscopical investigation, electron microscopy, and Bayesian phylogenetic inference using haplosporidian 165 rRNA gene sequences.

Results: In stained sections, the haplosporidian was observed to cause systemic infections in Diporeia that were often accompanied with host tissue degeneration. The haplosporidian appeared as binucleate plasmodia and sporocysts containing different spore maturation stages in the coelom, connective tissue, digestive tissue, and muscle. All of the observed systemic infections progressed to sporogenesis. Transmission electron microscopy revealed that fixed mature spores were slightly ellipsoidal and had a mean spore length $X$ width of $5.34 \pm 0.17 \times 4.09 \pm 0.15 \mu \mathrm{m}$. A hinged opercular lid with a length of $3.1 \pm 0.17 \mu \mathrm{m}$ was observed for a number of developing spores. The average thickness of the cell wall was $90.0 \pm 8.33 \mathrm{~nm}$. Thin filaments $(70 \mathrm{~nm})$ composed of spore wall material were observed projecting from an abopercular thickening of the spore wall. Phylogenetic analysis showed that the haplosporidian is novel bearing some similarities with the oyster pathogen Haplosporidium nelsoni, yet distinctly different.

Conclusions: Based on its morphology, genetic sequence, and host, it became evident that the Diporeia haplosporidian is taxonomically novel and we propose its nomenclature as Haplosporidium diporeiae. This is the first report of a haplosporidian infecting Diporeia in Lake Superior.

\section{Background}

Haplosporidians are spore-producing, endoparasitic protists that parasitize a range of marine [1] and freshwater [2-4] invertebrates. Currently, four genera have been assigned to the phylum- Urosporidium, Minchinia, Bonamia, and Haplosporidium, and generic assignment has been largely determined by presence or absence of a hinged operculum

\footnotetext{
* Correspondence: faisal@crm.msu.edu

${ }^{2}$ Pathobiology and Diagnostic Investigation, Michigan State University, 48824 East Lansing, Michigan, USA

Full list of author information is available at the end of the article
}

on the outer surface of the anterior orifice and the origin of spore wall ornamentation [5-9]. Urosporidium are characterized by an internal flap of spore wall material covering the spore orifice, while the other three genera exhibit an external hinged operculum. Minchinia have cytoplasmic extensions originating from the epispore that disappear at the end of sporulation while Bonamia and Haplosporidium have ornamentation that is derived from the spore wall. Although recent molecular phylogenetic studies have confirmed the monophyly of Haplosporidia and shed light on the diversity of each 
genera, including Bonamia for which spores have only been characterized in one species $[6,10]$, they revealed an incongruence of molecular phylogeny of the Haplosporidia and the generic definition based on morphological characterization $[7,11]$.

In mollusks, haplosporidians have been reported to cause a range of lesions, from destruction of gills, gonads, or digestive gland to general destruction of all associated tissues [4,12-15]. In the brackish environment, Haplosporidium nelsoni, the causative agent of MSX disease, has contributed to major mortalities in the eastern oyster (Crassostrea virginica) populations along the eastern coast of the United States for decades [16]. In the freshwater environment, Haplosporidium pickfordi was found infecting the digestive gland of snails in multiple lakes in northern Michigan, USA $[17,18]$ with limited evidence that the parasite is pathogenic to its hosts. Additionally, one species $(H$. raabei) was reported in the connective tissue of the gills, gonads, and digestive gland of zebra mussels (Dreissena polymorpha) from the Rhine and Meuse river basins in France, Germany, and the Netherlands [4].

Less is known regarding haplosporidian infections in amphipods. In Rivulogammarus pulex, Haplosporidium gammari has been shown to develop systemically in adipose tissue and destroy fat cells [19]. In Parhyale hawaiensis, infections by two different unidentified haplosporidians were associated with tissue damage that ranged from stretching, swelling, and fusion to vacuolation, fragmentation, and liquefaction necrosis of digestive epithelial cells and necrosis and rupture of skeletal muscle fibers surrounding the digestive canal and hepatopancreas [20]. Additionally, a range of microorganisms including unidentified haplosporidians have been observed infecting amphipods belonging to the genus Diporeia, a genus of amphipods for which taxonomic differences have not been resolved [[3,21,22] Nalepa and Faisal: Mechanistic approach to identify the role of pathogens in causing Diporeia decline in the Laurentian Great Lakes, Final Report, submitted]. The aim of the current study is to use microscopical and molecular techniques to determine the infection characteristics and phylogenetic relationship of a haplosporidian infecting Diporeia spp. (Diporeia) in the Laurentian Great Lakes (USA).

\section{Methods}

\section{Sample collection and morphological examination}

In August 2008, a total of 332 Diporeia from four sites in Lake Superior (Figure 1) and a single pooled Diporeia sample (10 amphipods) from a site in Lake Michigan $\left(45^{\circ} 10.7000 \mathrm{~N}, 086^{\circ} 22.5403 \mathrm{~W}\right)$ were collected for determining the presence of haplosporidian infection. Samples were collected by taking Ponar grabs (sampling area $9 \times 9$ "/ 8.2 liters) at depths between 18-136 meters).
Benthic samples were sieved (mesh $=0.25 \mathrm{~mm}$ ) and Diporeia were identified according to [23] and placed in either $10 \%$ neutral buffered formalin for histopathological analysis or filter-sterile $(0.2 \mu \mathrm{m}) 80 \%$ ethanol for molecular analysis. Due to the low density of amphipods at the sites sampled and the low prevalence of haplosporidian infection in Diporeia [21], wet mounts of fresh samples were not prepared and screened for haplosporidian infection. Therefore, fresh haplosporidians were not immediately preserved in a glutaraldehyde solution for ultrastructural studies using transmission electron microscopy.

For histopathological analysis, amphipods preserved in formalin were dehydrated in a graded series of alcohols, embedded in paraffin, cut into 3-4 $\mu \mathrm{m}$ thick serial sections, and stained with hematoxylin and eosin. An average of 83 amphipods was sampled from each site. The taxonomic system for haplosporidia infecting Diporeia was based on the morphological criteria used for taxonomy detailed in [24]. To ascertain morphological similarities of haplosporidians infecting Great Lakes Diporeia, we compared the haplosporidian development stages observed in Lake Superior Diporeia with 1) those observed in samples of Diporeia collected from nine sites in southern Lake Michigan between 1980 and 2007 (Nalepa and Faisal: Mechanistic approach to identify the role of pathogens in causing Diporeia spp. decline in the Laurentian Great Lakes, Final Report, submitted) and 2) those reported in $[3,21]$.

Ultrastructural studies were performed on representative, infected Diporeia samples collected from site SU-23B in Lake Superior that were embedded in a paraffin block. Samples were deparaffinized, post-fixed, and processed for transmission electron microscopy (TEM). For TEM, ultra-thin sections $(60-100 \mathrm{~nm})$ were stained with $2 \%$ $(\mathrm{w} / \mathrm{v})$ uranyl acetate in $50 \%$ ethanol followed by Reynold's lead citrate and examined in a JEM-100 CX II electron microscope at an accelerating voltage of $100 \mathrm{kV}$.

\section{DNA isolation, amplification, and sequencing}

Genomic DNA from an infected Diporeia collected from the same sampling station in Lake Superior was extracted using the DNeasy DNA extraction kit (QIAGEN) according to the manufacturer's instructions. PCR amplification of $16 \mathrm{~S}$ rDNA was amplified according to the protocol of [4]. Specifically, the HAP-F1 $+16 S-B$ primer set was initially used to screen Lake Superior Diporeia populations for haplosporidian 16S rRNA genes. A negative control containing no DNA was included in the PCR reaction. The resulting PCR products were visualized by agarose gel electrophoresis to confirm only a single fragment was amplified, cloned using a TOPO TA Cloning $\mathrm{Kit}^{\circ}$ (Invitrogen, CA, USA) following the manufacturer's protocol, cultured on Luria-Bertani agar plates (Fisher Scientific 


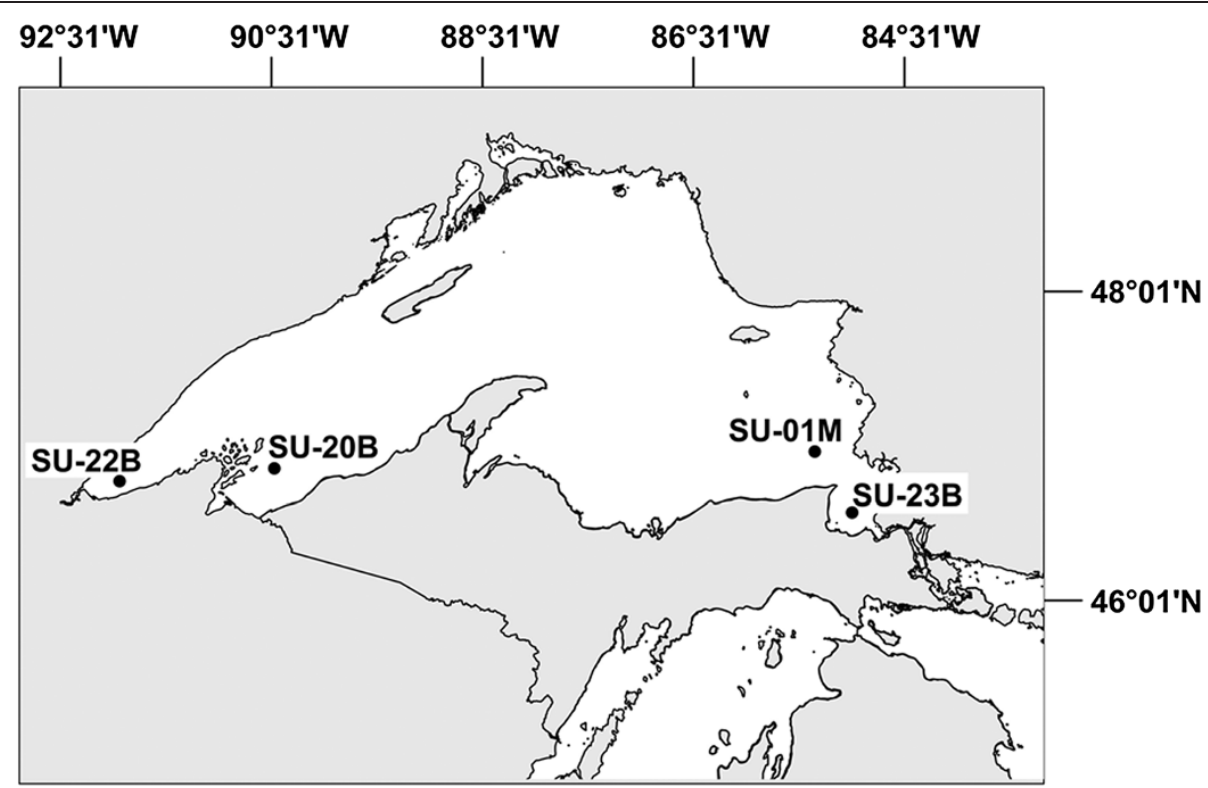

Figure 1 Sampling sites in Lake Superior (USA) where Diporeia specimens were examined for a haplosporidian infection.

Inc., PA, USA) containing $50 \mu \mathrm{g} / \mathrm{ml}$ Kanamycin as directed by the manufacturer's protocol, and sequenced using the M13f (5'-GTT TTC CCA GTC ACG AC-3'), M13r (5'-CAG GAA ACA GCT ATG ACC-3') and amplification primers. The resulting sequences were deposited in GenBank (Accession numbers: KF378734 and KM058119.

\section{Sequence and phylogenetic analyses}

The 16S rRNA gene sequences were submitted for BLAST (National Center for Biotechnology Information) searches and highly similar matches were included in the dataset for phylogenetic analysis. Selection of sequences to include in phylogenetic analyses was based on the findings of $[9,25]$. A total of 19 haplosporidian and three nonhaplosporidian outgroup 16S rRNA gene sequences were aligned with ClustalW as implemented in MEGA 5.0 [26] using default settings. The average length of sequences in the final alignment file was $1,754 \mathrm{bp}$. The alignment file was visually checked for alignment gaps and missing data in nucleotide positions.

Prior to phylogenetic analysis, the program jModelTest [27] was used to select the best fitting substitution model according to the corrected Akaike information criterion (AICc) [28]; the model with the lowest AICc value was identified as the best model in terms of fit and parsimony [29]. A total of 1,624 candidate models, including models with equal/unequal base frequencies, with/without a proportion of invariable sites $(+\mathrm{I})$, and with/without rate variation among sites $(+G)$ were tested. The best-fit model of nucleotide substitution was the transitional model [30] with $\gamma$ distributed rates $(\mathrm{TIM}+\mathrm{I}+\mathrm{G})$ with unequal base frequencies.

Tree topologies were inferred using a Bayesian approach using MRBAYES v 3.1.2 [31]. For Bayesian analysis, we used the GTR $+\mathrm{I}+\mathrm{G}$ model of nucleotide substitution, given that it is the model available in MRBAYES that best matches the TIM + I + G model. Bayesian analysis included four Monte Carlo Markov chains (MCMC) for 2,000,000 generations, and trees sampled every 1,000 th generation. The first $25 \%$ of samples were discarded as burn-in. After discarding the burn-in samples, the remaining data were used to generate a $50 \%$ majority-consensus tree.

\section{Results}

\section{Pathology and morphological characterization}

Haplosporidian infections were observed in Diporeia collected from all four sites in Lake Superior (Table 1). Prevalence ranged from $1.08 \%$ in site SU-22B, to $2.97 \%$ in site SU-20B making an overall prevalence of $2.11 \%$. In all infected Diporeia (7/7), haplosporidian developmental stages were widespread and distributed in a systemic way and all had progressed to sporogenesis. Plasmodial development and sporogenesis was relatively synchronous. For all observed infections, plasmodia and developing spores were observed in high densities throughout the coelom. Additionally, developing spores were often associated with connective, digestive, and muscle tissues. Plasmodia and sporocysts were commonly observed lining the epicuticle and digestive tissue (Figure 2A). Infections were often accompanied by degeneration of host tissues. An apparent 
Table 1 Samples in which haplosporidian infection was observed in sections of Diporeia collected from Lake Superior in 2008

\begin{tabular}{lllll}
\hline Site & Coordinates & Depth $(\mathbf{m})$ & Month/year sampled & Prevalence \\
\hline SU-01 M & $46.99^{\circ} \mathrm{N} \& 85.16^{\circ} \mathrm{W}$ & 95 & $8 / 2008$ & $2.94 \%(2 / 68)$ \\
SU-20B & $46.88^{\circ} \mathrm{N} \& 90.28^{\circ} \mathrm{W}$ & 113 & $8 / 2008$ & $2.97 \%(3 / 101)$ \\
SU-22B & $46.80^{\circ} \mathrm{N} \& 91.75^{\circ} \mathrm{W}$ & 53 & $8 / 2008$ & $1.08 \%(1 / 93)$ \\
SU-23B & $46.60^{\circ} \mathrm{N} \& 84.81^{\circ} \mathrm{W}$ & 60 & $8 / 2008$ & $1.43 \%(1 / 70)$ \\
\hline
\end{tabular}

host response to infection was observed as differentiated, melanized circulating host hemocytes surrounding sporocysts.

Stained, paraffin-embedded sections revealed that the haplosporidian spores within Lake Superior Diporeia were contained in round to amorphous sporocysts averaging $29.09 \pm 3.20 \mu \mathrm{m}(\mathrm{n}=8)$ in length ranging from 19.94 to $42.47 \mu \mathrm{m}$. TEM of the sample collected from SU-23B revealed the presence of both immature spores that were amorphous and electron-dense and spherical to slightly ellipsoidal mature spores that exhibited a lower electron density within sporocysts (Figure 2B).

In stained histological sections, sporoblasts with a well-defined endosporoplasm often containing two basophilic bodies were observed (Figure 2C). Sporocysts often contained mature spores with a well-defined, basophilic endosporoplasm. As described for Haplosporidium by [32], mature spores were observed outside of sporocysts and multiple spores showed what appeared to be thin filaments projecting from the abopercular end of the spore (Figure 2D).

By TEM, individual spores measured $5.34 \pm 0.17 \mu \mathrm{m}$ long by $X 4.09 \pm 0.15, \mu \mathrm{m}$ wide $(n=14)$. The average thickness of the cell wall was $90.0 \mathrm{~nm}(\mathrm{SE}=8.33, \mathrm{n}=6)$. A hinged opercular lid with a length of $3.1 \pm 0.17 \mu \mathrm{m}$ $(n=6)$ composed of spore wall material was observed for a number of developing spores (Figure 3A). A thickening of the spore wall at the abopercular end was observed for several mature spores (Figure 3B). Thin filaments $(70 \mathrm{~nm})$ that appear to be composed of spore wall material appeared to project from the abopercular thickening (Figure 3C).

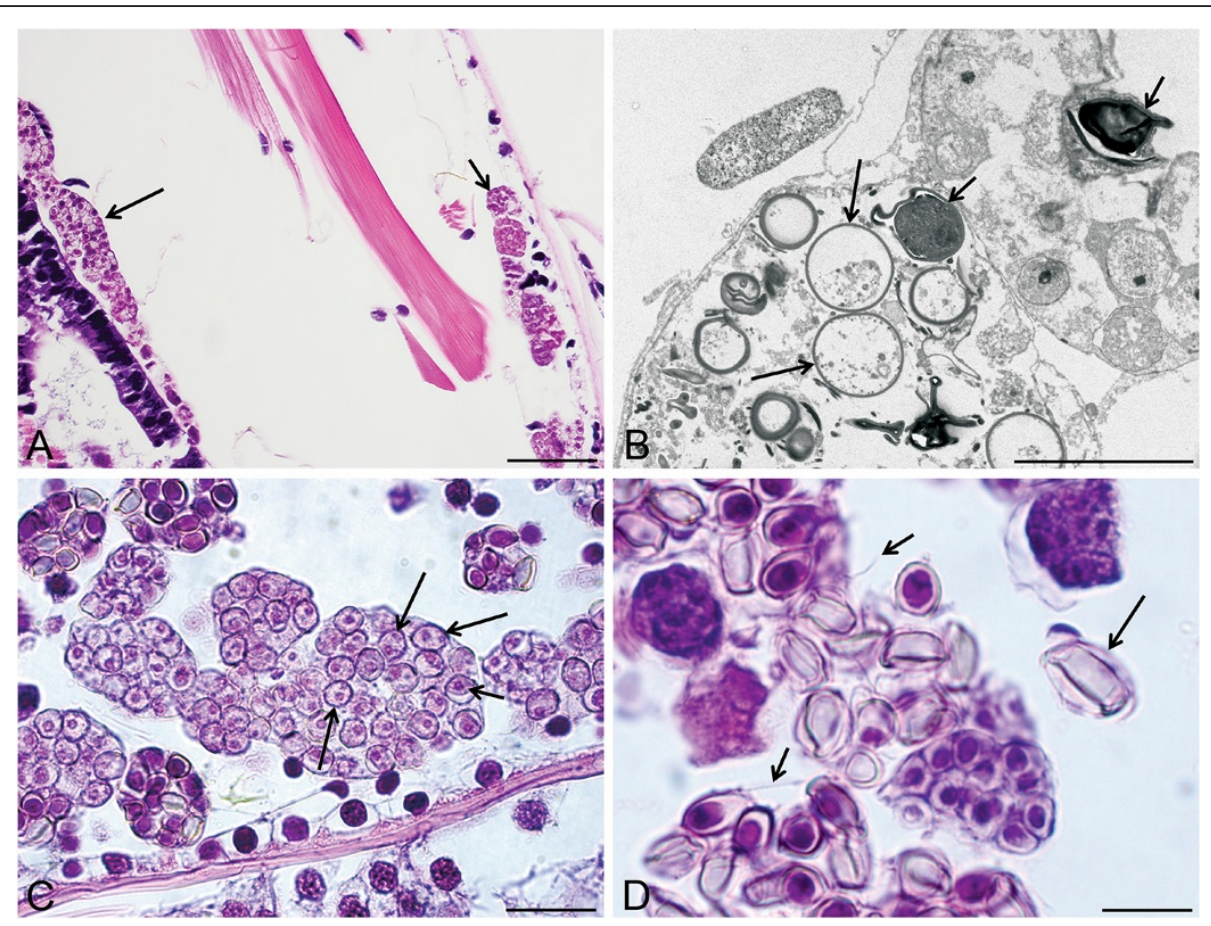

Figure 2 Histological sections of haplosporidian in Diporeia collected from Lake Superior (USA). (A) Plasmodia undergoing various stages of shizogeny lining the epicuticle (small arrow) and sporocysts containing developing spores lining host digestive tissue (large arrow). (B) Transmission electron micrograph of sporocysts containing both amorphous, immature spores (small arrows) and mature spores (large arrows). (C) Sporoblast containing two basophilic bodies (large arrows). Note the sporoblast with a well-defined endosporoplasm (small arrow). (D) Mature spore that has been liberated from the sporocyst (large arrow) and thin filaments projecting from the end of multiple developing spores (small arrows). Scale bars: A = $75 \mu \mathrm{m}$, $B=10 \mu \mathrm{m}, C=25 \mu \mathrm{m}$, and $\mathrm{D}=5 \mu \mathrm{m}$. 


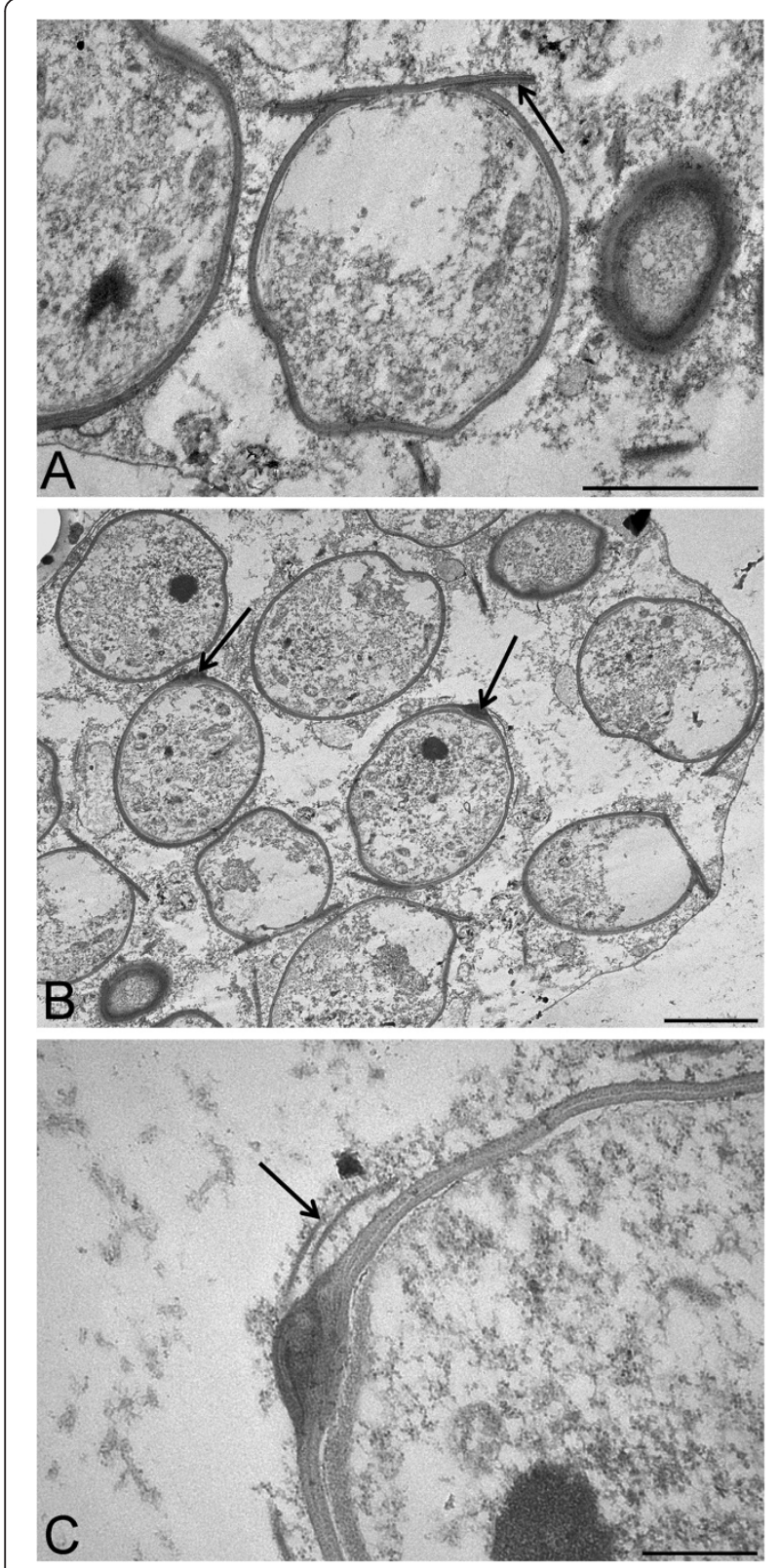

Figure 3 Transmission electron micrographs of haplosporidian infecting Diporeia in Lake Superior. (A) Spore with a hinged opercular lid (arrow). (B) Spores exhibiting a thickening of the spore wall at the abopercular end (arrows). (C) Mature spore exhibiting what appears to be thin filaments projecting from a thickening of the cell wall (arrow). Scale bars: $A=2,000 \mathrm{~nm}, B=2,500 \mathrm{~nm}$, and $C=500 \mathrm{~nm}$.

\section{Phylogenetic analysis}

The 16S rDNA sequences obtained from haplosporidians infecting multiple Diporeia in Lakes Superior (1,522 bp) and Michigan (545 bp) were identical over the nucleotide positions covered by both sequences. Pairwise comparison of the consensus $16 \mathrm{~S}$ rDNA sequence of the haplosporidian obtained from Diporeia to other closely related haplosporidians showed that the Diporeia haplosporidian was most similar to Haplosporidium nelsoni sequences (GenBank Accessions U19538 and AB080597). The resulting tree of phylogenetic inference had the genus Haplosporidium as paraphyletic as previously reported $[9,25]$, and showed that the sequence obtained from the Diporeia haplosporidian aligned with $H$. nelsoni but was distinctly different (Figure 4). Posterior probabilities of branching points based on Bayesian inference indicated that the node support of the Lake Superior Diporeia taxon was $96 \%$, strongly suggesting that the haplosporidian infecting Lake Superior Diporeia is a novel species of Haplosporidium.

\section{Discussion}

Results of both morphological (Table 2) and molecular (Table 3) analyses indicate the Diporeia haplosporidian is novel. In comparison to the Diporeia haplosporidian, all similar haplosporidian strains had a $16 \mathrm{~S}$ rDNA sequence dissimilarity of $1.2 \%$ or greater indicating the Diporeia haplosporidian is novel. While phylogenetic analysis showed that the Diporeia haplosporidian was most similar to the oyster pathogen $H$. nelsoni, the Diporeia haplosporidian formed a separate clade in the tree with high node support (96\% posterior probability) suggesting it is distinctly different from $H$. nelsoni. The phylogenetic relationship between these two haplosporidians is also reflected in their spore morphologies as well since both have similar spore ornamentation (i.e., filaments composed of spore wall material projecting away from the spore wall) however, the spores of the haplosporidian observed infecting Diporeia are smaller than those of $H$. nelsoni.

As with $H$. nelsoni, the Diporeia haplosporidian can be distinguished from the other five recognized freshwater species by its smaller spore size (Table 2). In comparison to $H$. pickforii, both haplosporidians are reported to infect invertebrates in Michigan (USA) and have an abopercular thickening of the spore wall [2]. However, in addition to having somewhat smaller spores, the Diporeia haplosporidian has thinner filaments than that reported for $H$. pickfordi [2]. Additionally, phylogenetic analysis shows that the two species are considerably different (82\% sequence similarity) (Table 3 ).

The finding that identical $16 \mathrm{~S}$ rDNA sequences were obtained from haplosporidians infecting multiple Diporeia in Lakes Superior and Michigan suggests that the same haplosporidian infects Diporeia populations residing within both the lakes. Additionally, the haplosporidian described in this study is morphologically similar to those previously described in Lakes Michigan and Huron Diporeia (i.e. spores with a hinged operculum and filaments emanating from a small thickening on the abopercular end) $[3,21]$ and thus may be the same species. Similarly, the observed prevalence of haplosporidian infections in Lake Superior Diporeia populations (1.1-3.0\%) is relatively similar to 


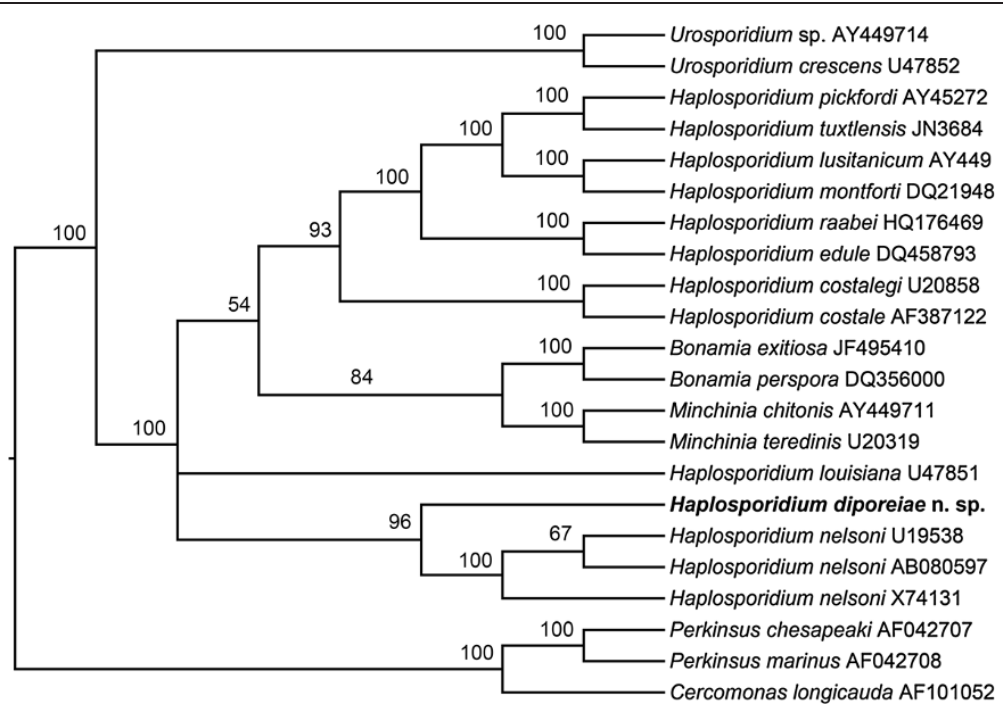

Figure 4 Phylogenetic tree (50\% majority-rule consensus) based on Bayesian Inference (MrBayes 3.1.2) of Haplosporidia based on the small subunit ribosomal gene. Numbers at the nodes are Bayesian posterior probabilities. Cercomonas longicauda, Perkinsus chesapeaki, and $P$. marinus were used as an outgroup for Haplosporidia based on the results of Reece et al. [9].

those previously reported in Diporeia populations in Lake Michigan (0.3-2.0\%) and Huron (1.0\%) [21]. However, the haplosporidian infecting Diporeia from Lakes Michigan and Huron were only detected in the hemal sinuses with no obvious tissue damage or host response, whereas the haplosporidian infections observed in this study were detected in multiple tissues and were associated with degeneration of multiple tissues and a pronounced host response. Further investigation of the relatedness of haplosporidians infecting Diporeia in Lakes Superior and Michigan as well as elsewhere in the Laurentian Great Lakes Basin is warranted.

This is the first report of a haplosporidian infecting Diporeia in Lake Superior. Based on its morphology,

Table 2 Morphological characteristics of all described freshwater species of Haplosporidia and those of Haplosporidium nelsoni compared to $H$. diporeiae n. sp

\begin{tabular}{|c|c|c|c|c|c|}
\hline Haplosporidium sp. & Host & $\begin{array}{l}\text { Mean spore } \\
\text { length, range ( } \mu \mathrm{m})\end{array}$ & $\begin{array}{l}\text { Mean spore } \\
\text { width, range }(\mu \mathrm{m})\end{array}$ & Location & Reference \\
\hline \multirow[t]{2}{*}{ H. diporeiae n. sp.* } & \multirow[t]{2}{*}{ Diporeia spp. } & 5.3 & 4.1 & \multirow[t]{2}{*}{ Lake Superior (USA) } & \multirow[t]{2}{*}{ This study } \\
\hline & & $4.4-6.7$ & $3.0-4.9$ & & \\
\hline Haplosporidium sp.* & Diporeia spp. & 8.1 range not stated & 6.1 range not stated & $\begin{array}{l}\text { Lakes Michigan and } \\
\text { Huron }\end{array}$ & Messick et al. [21] \\
\hline Haplosporidium sp.* & Diporeia spp. & $\begin{array}{l}8.1 \pm \text { SE } 0.23 \text { range } \\
\text { not stated }\end{array}$ & $\begin{array}{l}6.1 \pm \text { SE } 0.16 \text { range } \\
\text { not stated }\end{array}$ & $\begin{array}{l}\text { Lakes Michigan and } \\
\text { Huron }\end{array}$ & Messick, [3] \\
\hline H. nelsoni & $\begin{array}{l}\text { Oysters Crassostrea virginica, } \\
\text { C. gigas }\end{array}$ & $8.15 .3-10.7$ & $5.54 .8-7.5$ & $\begin{array}{l}\text { East Coast of North } \\
\text { America }\end{array}$ & Perkins, [33] \\
\hline H. cernosvitovi & $\begin{array}{l}\text { Oligochaetes Opistocysta } \\
\text { flagellum }\end{array}$ & $\begin{array}{l}\text { Mean not stated } \\
10-11\end{array}$ & Mean not stated 6-7 & & Jírovic, [34] \\
\hline H. limnodrili & $\begin{array}{l}\text { Oligochaetes Limnodrilus } \\
\text { udekemianu }\end{array}$ & $\begin{array}{l}\text { Mean not stated } \\
10-12\end{array}$ & Mean not stated 8-10 & & Granata, [35] \\
\hline \multirow[t]{2}{*}{ H. pickfordi } & \multirow{2}{*}{$\begin{array}{l}\text { Snails Physella parkeri, } \\
\text { Lymnaea stagnalis, and } \\
\text { Heliosoma companulatum }\end{array}$} & $8 \cdot 9$ & $4 \cdot 5$ & \multirow{2}{*}{$\begin{array}{l}\text { Lakes in northern } \\
\text { Michigan, USA }\end{array}$} & \multirow[t]{2}{*}{ Barrow, [17] } \\
\hline & & $8 \cdot 5-10 \cdot 4$ & $3 \cdot 8-4 \cdot 6$ & & \\
\hline \multirow[t]{2}{*}{ H. raabei } & \multirow{2}{*}{$\begin{array}{l}\text { Zebra mussels Dreissena } \\
\text { polymorpha }\end{array}$} & $7 \cdot 5$ & $5 \cdot 2$ & \multirow[t]{2}{*}{ Meuse River (France) } & \multirow[t]{2}{*}{ Molloy et al. [4] } \\
\hline & & $6 \cdot 5-9 \cdot 4$ & $4 \cdot 5-5 \cdot 9$ & & \\
\hline H. vejdovskii & $\begin{array}{l}\text { Oligochaetes Mesenchytraeus } \\
\text { flaviduus }\end{array}$ & $\begin{array}{l}\text { Mean not stated } \\
10-12\end{array}$ & Mean not stated 8-10 & & $\begin{array}{l}\text { Caullery and } \\
\text { Mesnil, [36] }\end{array}$ \\
\hline
\end{tabular}

$\left(^{*}\right)$ indicates haplosporidians for which spore measurements were made from fixed material. 
Table 3 Pairwise genetic distances between Haplosporidium diporeiae $\mathbf{n}$. sp. and similar haplosporidians based the partial $16 \mathrm{~S}$ small subunit rDNA sequences used for phylogenetic analysis

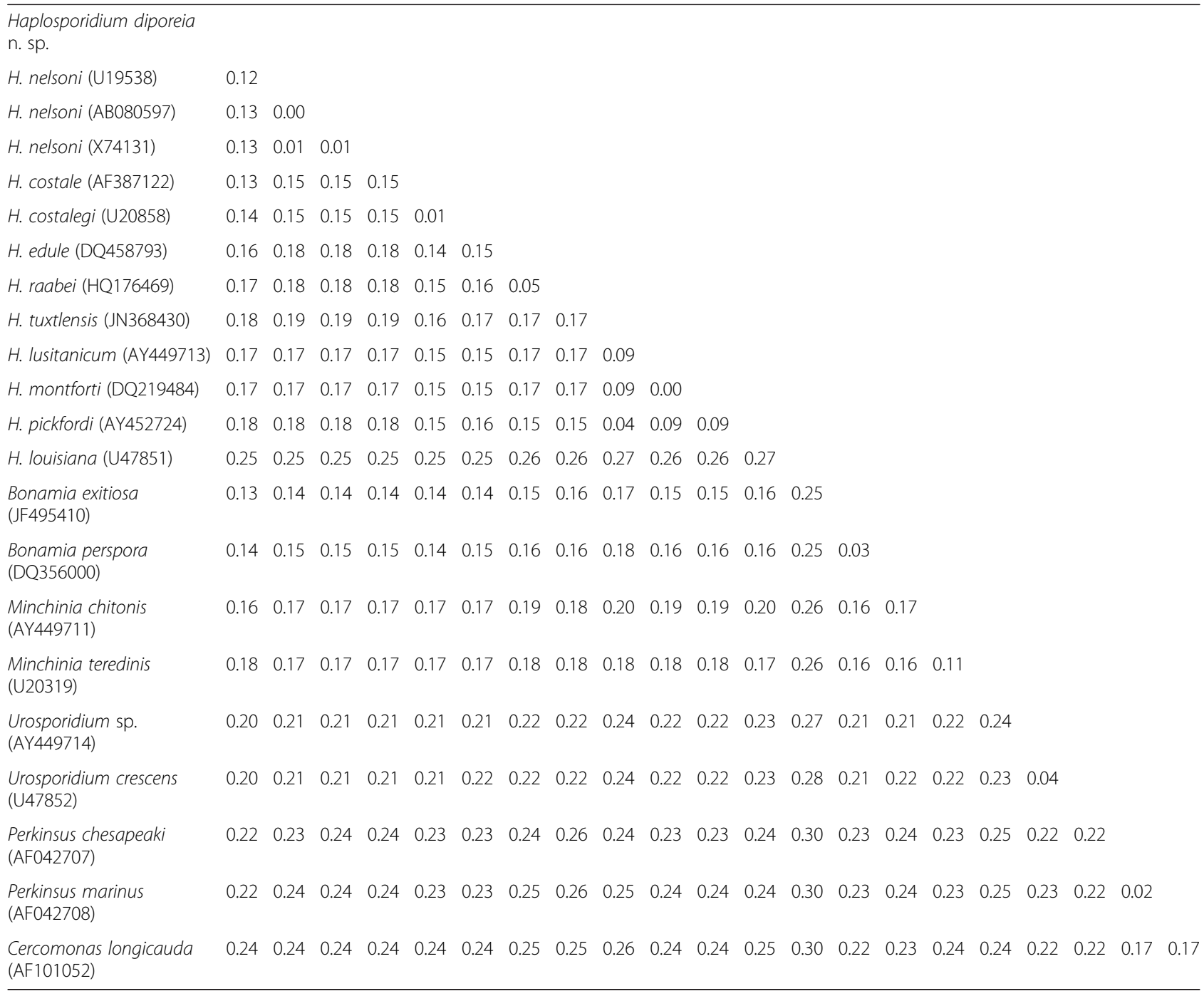

genetic sequence, and host, this is a novel Haplosporidium sp., for which the name Haplosporidium diporeiae n. sp. is proposed.

\section{Conclusion}

\section{Description of Haplosporidium diporeiae}

Taxonomic summary

Phylum Haplosporidia [37]

Class Haplosporea

Order Haplosporida

Family Haplosporidiidae

Haplosporidium diporeiae n. sp.

\section{Description}

Spherical to slightly ellipsoidal $(5.34 \pm 0.17 \times 4.09 \pm 0.15 \mu \mathrm{m})$ spores are present throughout coelom, connective, digestive, and muscle tissues. Binucleate plasmodia. Plasmodia contain two nuclei. Plasmodia and sporocysts are typically up to about $30 \mu \mathrm{m}$ in width. Developing spores have a hinged opercular lid with a length of $3.1 \pm 0.17 \mu \mathrm{m}$ composed of spore wall material. The spore wall is thickened at the abopercular end with individual string-like projections.

\section{Type host}

Diporeia sp.

Amphipoda, Gammaridae, Phoxocephaloidae, Haustoriidae

Type locality

Lake Superior (USA)

Sampling site SU-23B $\left(46.60^{\circ} \mathrm{N} \& 84.81^{\circ} \mathrm{W}\right)$

Depth $=60 \mathrm{~m}$

\section{Type material}

Reference materials are deposited at

The U.S. National Parasite Collection, U.S. Department of Agriculture, Beltsville, MD. 
USNPC number 107252.00 .

Ribosomal DNA sequence: Deposited to GenBank.

Accession number KF378734.

In accordance with section 8.5 of the ICZN's International Code of Zoological Nomenclature, details of the new species have been submitted to ZooBank with the life science identifier (LSID) zoobank.org:pub:0B34CB35-B44748AA-A0DA-C00E81EA7940.

\section{Etymology}

The specific epithet refers the genus of the host Diporeia.

\section{Competing interests}

The authors declare that they have no competing interests.

\section{Authors' contributions}

ADW and MF conceived the idea and designed the investigation. ADW performed the microscopical and molecular work. ADW and MF wrote the paper. Both authors read and approved the final version of the manuscript.

\section{Acknowledgements}

The authors would like to thank the Great Lakes Fisheries Trust (Grant \# GL00E361) and the United States Environmental Protection Agency - Great Lakes National Protection Office (Grant \#: GLO0E36101) for their generous support of this study. We also would like to thank Mr. Tom Nalepa of the National Oceanic and Atmospheric Administration - Great Lakes Environmental Research Laboratory for donating Diporeia samples collected prior to 2008

\section{Author details}

'Department of Fisheries and Wildlife, Michigan State University, 48824 East Lansing, Michigan, USA. ${ }^{2}$ Pathobiology and Diagnostic Investigation, Michigan State University, 48824 East Lansing, Michigan, USA.

Received: 14 March 2014 Accepted: 27 June 2014

Published: 24 July 2014

\section{References}

1. Perkins FO: Phylum Haplosporidia Caullery \& Mesnil, 1899. In The illustrated guide to the Protozoa. Soc Protozool Lawrence, KS. Edited by Lee JJ, Leedale GF, Bradbury P. : 2000:1329-1341.

2. Burresson EM: Spore ornamentation of Haplosporidium pickfordi Barrow, 1961 (Haplosporidia), a parasite of freshwater snails in Michigan, USA. J Eukaryot Microbiol 2001, 48:622-626.

3. Messick GA: Haplosporidian parasite in Diporeia spp. amphipods from the Great Lakes region, USA. Dis Aquat Org 2009, 83:153-157.

4. Molloy DP, Giamberini L, Stokes NA, Burreson EM, Ovcharenko MA: Haplosporidium raabei n. sp. (Haplosporidia): a parasite of zebra mussels, Dreissena polymorpha (Pallas, 1771). J Parasitol 2012, 139:463-477.

5. Azevedo C, Montes J, Corral L: A revised description of Haplosporidium armoricanum, parasite of Ostrea edulis L. from Galicia, north western Spain, with special reference to the spore-wall filaments. Parasitol Res 1999, 85:977-983.

6. Azevedo C, Balseiro P, Casal G, Gestal C, Aranguren R, Stokes NA, Carnegie RB, Novoa B, Burreson EM, Figueras A: Ultrastructural and molecular characterization of Haplosporidium montforti n. sp., parasite of the European abalone Haliotis tuberculata. J Invertebr Pathol 2006, 92:23-32.

7. Burreson EM, Reece KS: Spore ornamentation of Haplosporidium nelsoni and Haplosporidium costale (Haplosporidia), and incongruence of molecular phylogeny and spore ornamentation in the Haplosporidia. J Parasitol 2006, 92:1295-1301.

8. Hine PM, Carnegie RB, Burreson EM, Engelsma MY: Inter-relationships of haplosporidians deduced from ultrastructural studies. Dis Aquat Org 2009, 83:247-256.

9. Reece KS, Siddall ME, Stokes NA, Burreson EM: Molecular phylogeny of the Haplosporidia based on two independent gene sequences. J Parasitol 2004, 90:1111-1122.
10. Carnegie RB, Burreson ME, Hine PM, Stokes NA, Audemard C, Bishop MJ, Peterson $\mathrm{CH}$ : Bonamia perspora n. sp. (Haplosporidia), a parasite of the oyster Ostreola equestris, is the first Bonamia species known to produce spores. J Eukaryot Microbiol 2006, 53:232-245.

11. Ituarte C, Bagnato E, Siddall M, Cremonte F: A new species of Haplosporidium Caullery \& Mesnil, 1899 in the marine false limpet Siphonaria lessonii (Gastropoda: Siphonariidae) from Patagonia. Syst Parasitol 2014, 88:63-73.

12. Ford SE, Haskin HH: History and epizootiology of Haplosporidium nelsoni (MSX), an oyster pathogen in Delaware Bay, 1957-1980. J Invertebr Pathol 1982, 40:118-141.

13. Ford SE: Comparison of hemolymph proteins from resistant and susceptible oysters, Crassostrea virginica, exposed to the parasite Haplosporidium nelsoni (MSX). J Invertebr Pathol 1986, 47:283-294.

14. Ford SE, Figueras A: Effects of sublethal infection by the parasite Haplosporidium nelsoni (MSX) on gametogenesis, spawning, and sex ratios of oysters in Delaware Bay, USA. Dis Aquat Org 1988, 4:121-133.

15. Bowmer C, Van Der Meer M: Reproduction and histopathological condition in first year zebra mussels (Dreissena polymorpha) from the Haringvliet, Volkerakmeer and Hollands Diep Basins, Delft, The Netherlands. TNO Inti Environ Sci Report 1991, 91:132.

16. Burreson EM, Ford SE: A review of recent information on the Haplosporidia, with special reference to Haplosporidium nelsoni (MSX disease). Aquat Living Resour 2004, 17:499-518.

17. Barrow JH: Observations of a haplosporidian, Haplosporidium pickfordi sp. nov. in fresh water snails. TAm Microsc Soc 1961, 80:319-329.

18. Barrow JH: Observations on Minchinia pickfordae (Barrow 1961) found in snails of the Great Lakes region. TAm MicrosC Soc 1965, 84:587-593.

19. Larsson Jl: On Haplosporidium gammari, a parasite of the amphipod Rivulogammarus pulex, and its relationships with the phylum Ascetospora. J Invertebr Pathol 1987, 49:159-169.

20. Ismail TG: Coexistence of two species of haplosporidian parasites in a population of the marine amphipod Parhyale hawaiensis with evidence for parasite phagocytosis and transmission mode. J Egypt Soc Parasito 2011, 41:227-241.

21. Messick GA, Overstreet RM, Nalepa TF, Tyler S: Prevalence of parasites in amphipods Diporeia spp. from Lakes Michigan and Huron, USA. Dis Aquat Org 2004, 59:159-170.

22. Faisal M, Winters AD: Detection of Viral Hemorrhagic Septicemia Virus (VHSV) from Diporeia spp. (Pontoporeiidae, Amphipoda) in the Laurentian Great Lakes, USA. Parasit Vectors 2011, 4:1-4

23. Bousfield E: Revised morphological relationships within the amphipod genera Pontoporeia and Gammaracanthus and the "glacial relict" significance of their postglacial distributions. Can J Fish Aquat Sci 1989, 46:1714-1725

24. Sprague V: Classification of the Haplosporidia. Mar Fish Rev 1979, 41:40-44

25. Burreson EM, Reece KS: Spore ornamentation of Haplosporidium nelsoni and Haplosporidium costale (Haplosporidia), and incongruence of molecular phylogeny and spore ornamentation in the Haplosporidia. J Parasitol 2009, 92:1295-1301.

26. Tamura K, Peterson D, Peterson N, Stecher G, Nei M, Kumar S: MEGA5: molecular evolutionary genetics analysis using maximum likelihood, evolutionary distance, and maximum parsimony methods. Mol Biol Evol 2011, 28:2731-2739

27. Darriba D, Taboada GL, Doallo R, Posada D: jModelTest 2: more models, new heuristics and parallel computing. Nat Methods 2012, 9:772.

28. Hurvich CM, Tsai CL: A corrected Akaike information criterion for vector autoregressive model selection. J Time Ser Anal 1993, 14:271-279.

29. Burnham KP, Anderson DR: Model selection and multi-model inference: a practical information-theoretic approach. New York: Springer; 2002.

30. Rodriguez F, Oliver J, Marin A, Medina JR: The general stochastic model of nucleotide substitution. J Theoret Biol 1990, 142:485-501.

31. Huelsenbeck JP, Ronquist F: MRBAYES: Bayesian inference of phylogenetic trees. Bioinformatics 2001, 17:754-755.

32. Perkins FO: Phylum Haplosporidia. In Handbook of Protoctista. Edited by Margulis JO, Corliss M, Melkonian Chapman DJ. Boston, MA: Jones and Bartlett; 1990:19-29.

33. Perkins FO: Fine structure of the oyster pathogen Minchinia nelsoni (Haplosporida, Haplosporidiidae). J Invertebr Pathol 1968, 10:287-305. 
34. Jirovic O: Haplosporidian cernosvitovi n. sp., eine neue Haplosporidienart aus Opistocysta (Pristina) flagellum Leidy. Archiv für Protistenkunde 1936, 86:500-508

35. Granata L: Ciclo di sviluppo di Haplosporidium limnodrili n. sp. Roma Rend Acc Lincei 1913, 22:734-737.

36. Caullery M, Mesnil F: Recherches sur les Haplosporidies. Archives de Zoologie Experimentale et Generale, IV Série 1905, 4:101-181.

37. Caullery M, Mesnil F: Sur quelques parasites internes des annelids. Traveaux de la Station Zoologique de Wimereux 1899, 7:80-99.

doi:10.1186/1756-3305-7-343

Cite this article as: Winters and Faisal: Molecular and ultrastructural

characterization of Haplosporidium diporeiae n. sp., a parasite of Diporeia

sp. (Amphipoda, Gammaridea) in the Laurentian Great Lakes (USA).

Parasites \& Vectors 2014 7:343.

\section{Submit your next manuscript to BioMed Central and take full advantage of:}

- Convenient online submission

- Thorough peer review

- No space constraints or color figure charges

- Immediate publication on acceptance

- Inclusion in PubMed, CAS, Scopus and Google Scholar

- Research which is freely available for redistribution 